Research Article

\title{
Measuring the Return on Investment of Training Modules of Electrical Protection and Uninterruptible Power Supply (UPS) Using the Corrective and AHP Approaches
}

\author{
Farhad Salimian \\ Department of Entrepreneurship Development, Faculty of Entrepreneurship, University of Tehran, Tehran, Iran \\ Correspondence should be addressed to Farhad Salimian; salimian.farhad@ut.ac.ir
}

Received 14 September 2021; Revised 7 November 2021; Accepted 29 November 2021; Published 18 December 2021

Academic Editor: Dragan Pamučar

Copyright (c) 2021 Farhad Salimian. This is an open access article distributed under the Creative Commons Attribution License, which permits unrestricted use, distribution, and reproduction in any medium, provided the original work is properly cited.

\begin{abstract}
The main purpose of this study is to calculate the return on investment of two training modules of electrical protection and uninterruptible power supply (UPS) using the corrective approaches applied to the basic model presented in previous research. In this study, first, the effect points of the training were identified using open questionnaires completed by experts. Then, its content validity is ensured by Lawshe, Waltz, and Basel approaches. Data on training costs were extracted through financial documentation and estimates. Details of measures, savings, internal supply, and so on were identified and cited to convert the observed effects into financial equivalents. Using the analytic hierarchy process (AHP) approach, the role of training in comparison with other initiatives in each of the effects and achievements was determined, and the net financial achievements of the training were determined. The training return on investment for the electrical protection module was $243 \%$ and for the UPS module was $1637 \%$.
\end{abstract}

\section{Introduction}

According to studies conducted so far, if employees are actively involved in training and development programs and increase their skills and knowledge to better use their responsibilities and authorities in line with the mission of the organization, they will show more effort in their work and show better performance outcomes [1]. In this context, there is ample evidence that managers are concerned with the significance of improving productivity and performance due to the training programs [2]. On the other hand, employees also consider training and development programs as part of performance improvement mechanisms. Such programs reduce the costs associated with dismissal and, as a result, attract and recruit a new replacement and trained staff. Not only does obtaining feedback on the effects of training help managers identify areas for improvement, but it also provides employees with the necessary knowledge about how to progress and develop their careers [3]. Therefore, in a new competitive business, having competent and flexible human resources is necessary. Part of the investment in human resources is allocated to the planning and implementation of training and development programs [4]. However, according to DeCenzo et al. [5], training and development are costly, and there are many pros and cons to the consequences [5]. Some of these actions have had financial consequences such as revenue, cost reduction, savings, and profitability, and some other reports have referred to nonfinancial aspects such as justice, customer satisfaction, reduced layoffs, and replacement of staff [6]. The return on investment (ROI) of training based on financial consequences is obvious, and its calculation is possible and practical. ROI is defined and understood in different ways by different stakeholders. However, many costs and benefits can be measured in terms of money and simply quantified [6]. The model presented in[7] pointed to the weakness of Kirkpatrick's model of not considering the costs and benefits of training and proposed this category as the fifth level of the Kirkpatrick model in evaluating the effectiveness of training. Rotem et al. [8] emphasized that the benefits of training should be inferred from the fourth level of the Kirkpatrick model and compared with the costs of training [8]. If the 
evaluation at the fourth level of the Kirkpatrick model is erroneous, the calculation of the ROI from training will also be erroneous.

The gas industry is one of the strategic industries in Iran and has a wide range of technical and economic activities. Iran ranks second in the world in terms of gas resources. The gas industry, as a core business, extracts, refines, and supplies gas, gas condensate, liquefied petroleum gas, and other products for domestic and external consumers, including ordinary people, industries, and export. The gas industry is one of the most important pillars of energy saving and food supply for other important industries such as petrochemicals. The main purpose of this study is to calculate the return on investment of two training modules of electrical protection and uninterruptible power supply (UPS) using the corrective approaches applied to the basic model presented in previous research. In this study, first, the effect points of the training were identified using open questionnaires completed by experts. Then, its content validity is ensured by Lawshe, Waltz, and Basel approaches. According to the explanations provided, it can be said that this study seeks to answer the following questions:

(i) What are the most important impact points of the practiced training and development programs?

(ii) What is the role of training in the outcomes and results observed in the organization and executive processes?

(iii) What is the rate of return on investment from training?

\section{Literature Review}

South Pars Gas Complex Company is one of the subsidiaries of the National Iranian Gas Company (NIGC), which was established in 1998 and is responsible for operating the onshore facilities of the multiple phases of the South Pars gas field. The South Pars refineries are located at sites 1 and 2 in Assaluyeh and Kangan counties, which contain 24 gas phases. Phases 1 to 10 and 15 to 21 are located at site 1 (Assaluyeh), and phases 11 to 14, phase 19, and phases 22 to 24 are located at site 2 (Kangan). The South Pars gas field is located in the territorial waters of Iran and Qatar and is shared between the two countries with an area of 6027 square miles and a depth of 1.9 miles below the seafloor. As the largest gas field in the world, it is $105 \mathrm{~km}$ away from the coast of Assaluyeh port. According to NIGC, the Iranian part covers an area of 2299 square miles, and its reserves are equivalent to $8 \%$ of the world's gas reserves and $50 \%$ of Iran's gas reserves. In terms of material resources, this field is the most important and valuable economic source and wealth and a huge and unique national treasure in Iran. In the field of training, the company pursues the mission of providing the necessary scientific and educational background for promoting organizational culture, transformation, and organizational growth and development by promoting the capabilities and competencies of managers and employees at the global level. The company's competitive vision requires that training programs be planned and implemented in the best possible way and that, as a company responsible for national investments, it could achieve the best possible ROI. Furthermore, by calculating the return on investment from training, it is possible to identify programs related to the real needs of the company and increase the variety of training programs in terms of title, content, and implementation methods. Also, in this way, the support of senior and middle managers in the field of staff training and development can be obtained.

Increasing competition requires that organizations continuously improve their processes and gain a competitive advantage in the new business [9]. Competitive advantage is the factor with which an organization can create a defensive position against competitors and includes capabilities that allow an organization to differentiate itself from competitors [10]. Competitive advantage is achieved by creating value for customers, and value is manifested by providing goods and services that are different from competitors at a lower price. Human resources have the potential to create a competitive advantage for the organization. In general, employee performance depends on several factors such as motivation, performance appraisal, job satisfaction, training, and development [11].

Researchers have introduced some prioritizing methods such as a combination of analytical hierarchy process (AHP) and Ranking of Alternatives through Functional mapping of criterion subintervals into a Single Interval (RAFSI) [12], Fuzzy Measurement Alternatives and Ranking according to Compromise Solution (FMARCOS) [13], third-party logistics [14], and Data-Envelopment-Analysis-based approach [15]. Moreover, the sensitivity analysis methods are also provided in the literature, including Full Consistency Method (FUCOM) [16], hybrid fuzzy MCDM [17], fuzzy Pivot Pairwise Relative Criteria Importance Assessment and fuzzy Measurement Alternatives and Ranking according to the Compromise Solution [18], Level Based Weight Assessment and fuzzy Multiattributive Border Approximation Area Comparison [19], and Best Worst Method and Multiattributive Ideal-Real Comparative Analysis [20].

Training and development are basically about creating perception, technical knowledge, techniques, and methods [21-23]. In fact, training and development are two of the necessities of human resource management. Because they can improve performance at the individual, administrative, and organizational levels, this is how today's organizations strive for inclusive and comprehensive training and development $[24,25]$. Training and development are not only an opportunity for growth but also an investment that has significant benefits for the organization and employees [26-28]. For the organization, training and development lead to improved profitability while at the same time creating more positive attitudes toward profit orientation. For employees, training and development of job knowledge improve and at the same time help them to understand the goals of the organization. Human capital distinguishes a great organization from a good one. Organizations that invest in effective training and development for their human resources tend to gain benefits in the short and long term. 
In 1975, Kirkpatrick designed his famous quadratic evaluation model, including reaction, learning, behavior, and results, for training programs. Phillips [29] noted the growing tendency for accountability in the form of higher levels of training evaluation that is relevant to business outcomes [29]. Based on the Kirkpatrick model, he concluded that there was a more prominent level of evaluation or the fifth level and called it an ROI. At this level of evaluation, the monetary value of the results is compared to the cost of the program and is usually expressed as a percentage. Despite the prominence of this evaluation, evaluators use it less than other evaluations because it is more difficult to manage and analyze. Phillips went on to show in a framework how monetary or financial amounts should be included in the value of training and the ROI of a training program, which is shown in Figure 1. Rooz [30] examined the rate of ROI from the leadership training program at the University of Georgia [31]. He considered two groups of managers as control and experimental and used the Phillips model. Data analysis showed that the dismissal and replacement rates for the trained group were significantly lower than the control group. The rate of ROI also showed that, for every dollar spent in the mentioned training program, a profit of \$ 3.86 was obtained, which in fact means $286 \%$ of the net return on investment in this investment. Sachdefa [32] addresses the challenges associated with measuring ROI and suggests how to address them in order to institutionalize the training ROI in organizations. The author categorized the challenges as the inability of human resource experts to collect data, lack of support and motivation of top managers, underestimation of achievable results, separation of the impact of training from other development programs, differences in the value of ROI outcome for managers at different levels and the need for them to agree on this, intangible benefits, and the risk of simplistic estimates to prove the constructive impact of training. There are several ways to detect faults in some studies in electrical systems, such as diagnosis based on $\mathrm{P}$ systems [33], microbially fault diagnostics depending on an initial set [34]; defect detection in energy systems based on fuzzy logic spiking neural P system [35], a failure analysis technique for three-phase motor drives [36], and $\mathrm{H}$ load frequency monitoring using event triggering [37].

Teixeira and Pereira [38] in their study confirmed that estimating and measuring the financial impact of human resource initiatives, including training and development programs, are not very common [38]. However, due to the high focus on training as a way to achieve business goals, it is important to ensure the proper implementation of these programs and determine the extent of their impact on the benefits. Thus, despite the difficulty of calculating the ROI and its high error rate, they have emphasized that if organizations do not use the necessary information and as a result make wrong decisions, they will not only waste financial resources, time, and human capital but may run the risk of losing talented employees and being deprived of business results.

\section{Methods and Materials}

3.1. Proposed Method. The present study is descriptive in terms of purpose and applied in terms of the type of use because it is an attempt to understand a specific situation in the
Isolate the effects of training

$\downarrow$

Determine the costs of implementing the training program

$\downarrow$

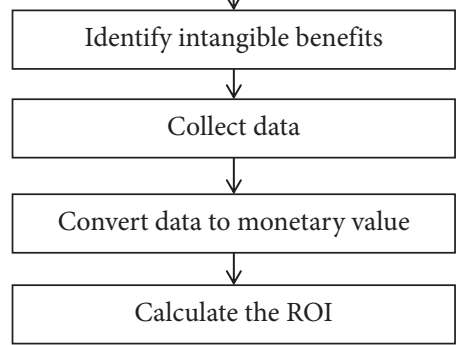

FIgURE 1: The framework of Phillips for calculating training return on investment.

real world in order to apply the findings to provide development solutions. Therefore, in terms of purpose, it is considered practical. This research is descriptive-case and is conducted in the field. Given that it follows the effects of training programs and the researcher has no role in those events, it is also considered postevent. It is a cross-sectional study in terms of time. Also, in terms of data type, it is a combination of qualitative and quantitative. The present study was started based on a library study in the field of calculating the training ROI and the use of training documents and records related to the two modules of electrical protection and uninterruptible power supply (UPS) and then using the points of view received through open and closed questionnaires provided to experts as well as performance information of the company and various units were followed. Given that this study was conducted for the first time in the company, the necessary information was unavailable. Therefore, it was necessary to gradually identify blind spots and ambiguities through documents and reports and refer to experts and experienced managers for clarification. The experts and stakeholders of both training modules were almost the same and included a total of twelve individuals, all of whom worked closely with the research team from the beginning to the end of the study. To identify the tangible effects and benefits of the modules, Lawshe, Waltz, and Basel approaches were used to ensure content validity.

The questionnaires used varied. The initial questionnaires were open-ended questionnaires for understanding technical events in the workplace, while the pairwise comparison questionnaire based on the analytic hierarchy process approach (AHP) was used to identify the role of the training program implemented in the updated functions. Expert choice software was used for its analysis. All data were collected and analyzed in coordination with experts and stakeholders through interviews and open and closed questionnaires, and the researchers had no involvement other than using the research mechanism. Therefore, the formal validity of the data is guaranteed. The research model is shown in Figure 2.

3.2. Analytical Hierarchy Process. The basis of this approach is to choose one option from several options, according to several specific criteria. This multicriteria evaluation method 


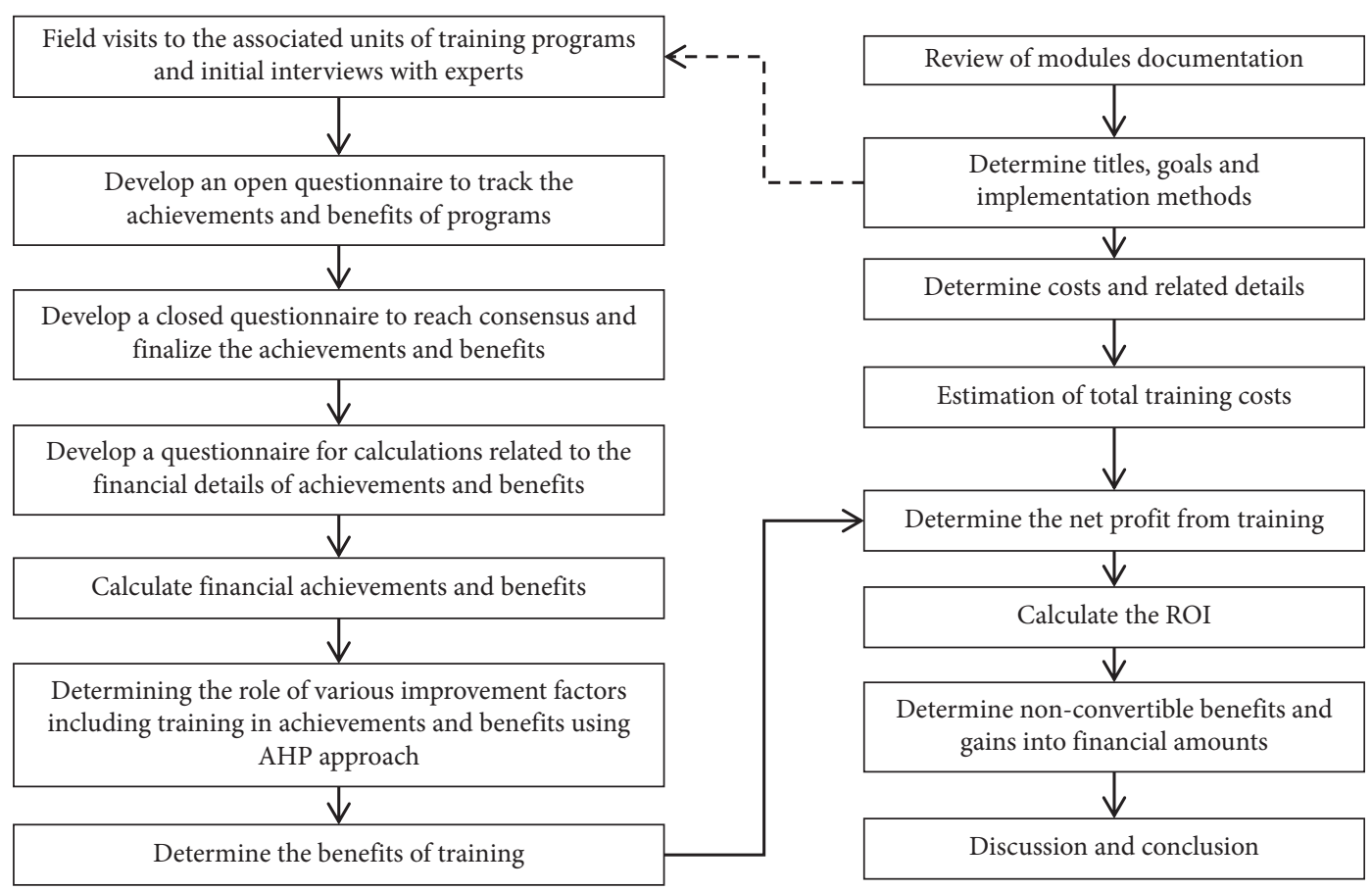

Figure 2: The research model used to calculate the ROI from training programs.

was first proposed in 1980 by Thomas L. Saati. Using the analytical hierarchy process (AHP) model, difficult and complex problems can be transformed into simple forms. This method has found many applications in economic and social issues and has found a special place in management.

The proposed criteria can be quantitative and qualitative. The basis of this decision-making method is based on pairwise comparisons. Decision-making begins with providing the decision hierarchy. The decision hierarchy tree shows the factors being compared and the competing options being evaluated in the decision. Then, a series of pairwise comparisons are made. These comparisons determine the weight of each factor in terms of competing options. Finally, matrices from pairwise comparisons are combined to make the optimal decision.

The first step based on this method is to determine the hierarchical diagram of the indicators and their pairwise comparisons with each other. This comparison is such that if element $i$ is compared with element $j$, the degree of importance of one over the other will be one of the states of "completely more important," "very strong importance," "strong importance," "less important," "importance is the same" which represent the values of $9,7,5,3$, and 1 , respectively. The importance between the distances is also indicated by the values $2,4,6$, and 8 . Weighing operations are performed in three ways: referring to the knowledge of experts and specialists, using data and documents, and also combining them. In order to calculate the weight of each of the criteria and options, the methods of ordinary least squares, logarithmic least squares, eigenvectors, and arithmetic mean can be used. In this research, Expert Choice software has been used to extract the weights.

3.3. Content Validity. The content validity ratio (CVR) is calculated based on equation (1). In order to calculate this ratio, experts' opinions on the content of the questionnaire are used, and by explaining the objectives of the questionnaire to them and providing them with operational definitions related to the content of the questions, they are asked to score each item based on the 3-point scale of " $n o t$ necessary, useful but not essential, essential." $p$ Questions for which the calculated CVR is less than the numeric value determined by the Lawshe table should be excluded from the questionnaire. The acceptable ratio for 10 respondents is 0.6 that has been applied.

$$
\mathrm{CVR}=\frac{\text { number of experts indicating }\} \text { essential }\}-(\text { total number of experts } / 2)}{(\text { total number of experts } / 2)}
$$

Waltz and Basel's method was used to examine the content validity index. Experts define each item as "relevant," "clear," and "simple" based on a four-part Likert scale. Experts rate each item as relevant from 1 to 4: 1 "not relevant," 2 "relatively relevant," 3 "relevant," and 4 "completely relevant." The clarity of a statement is determined from 1 to $4: 1$ "not clear," 2 "relatively clear," 3 "clear," and 4 "clearly relevant," respectively. The minimum 
acceptable value for the CVI is 0.79 , and if the CVI is less than 79.0, that item should be removed. The content validity index (CVI) was obtained from the following equation:

$$
\mathrm{CVI}=\frac{\text { number of experts rating item } 3 \text { or } 4}{\text { total number of experts }} \text {. }
$$

\section{Findings}

4.1. Training Modules. The two major modules studied in this study were electrical protection and UPS with 23 and 17 participants, respectively. Both of them were conducted in 2017 , and the duration of the modules was 48 hours.

4.2. Calculating Training Costs. A special form was used to calculate the costs of the studied modules, and it reflected the costs as much as possible. For cases where there was no documentation, subindices were used to estimate the costs. For example, items such as the salaries of the teaching staff were considered according to the time spent in different stages of training planning, from needs assessment to evaluation. Subindicators and standards were set to convert the activities performed into financial amounts. A detailed description of the training costs is provided in Table 1.

All real and estimated data were entered in Excel software and extracted financially related to each training module. The result related to training costs is shown in Table 2.

4.3. Impacts and Benefits Observed. During numerous observations, interviews, and careful examination of the details of the events reflected in the performance documentation and reports, the effects were clearly identified, and, separately, the financial benefits arising from them were determined. In the open questionnaires submitted to the experts, significant financial implications were included. Using the content validity approach, finally, five items were agreed upon, which are mentioned in Table 3.

The report of the effects related to the two training modules is shown in Tables 4-8. Given the importance of confidentiality and preventing possible abuse, some cases are not intentionally presented here.

Summarizing and calculating the total effects and achievement of the two training modules implemented show that the 5-year financial achievement of the electrical protection module is equal to $\$ 202,138$, and the 10 -year financial achievement of the UPS module is $\$ 1,797,099$.

4.4. The Role of Various Factors in the Benefits Obtained. Based on the agreement reached with the training officials as well as the beneficiaries of the implemented training, in general, seven important factors affecting the improvement of performance and gaining benefits were identified. Using the AHP approach and the defined pairwise comparison questionnaire, the weight of each of the mentioned factors in each of the observed or estimated effects was determined.
A total of twelve experts (six experts for each module) completed the questionnaires, and the geometric mean of their opinions was considered as the final number of pairwise comparisons. The results of the mentioned analysis are shown in Table 9.

4.5. Calculating the ROI of Training. According to the weight of training in the benefits and achievements, the share of training was calculated as the net profit from training, which is shown in Tables 10 and 11. By dividing the net profit by the cost of education, the ROI is obtained.

4.6. Determining the Nonconvertible Effects on Financial Values. By conducting surveys through dialogue with experts and obtaining their agreement, nonconvertible achievements into financial values were also considered as described in Table 12 for the modules held.

\section{Discussion}

Based on the quantitative data alone, 2.43 times the cost of 5 years for the electrical protection training module and 16.37 times the cost of 10 years for the UPS training module will be returned to the company. In this set of training programs, learners gained new knowledge about electrical protection and UPS and learned about the types of parts and materials suitable for use in work processes and the possibility of designing, manufacturing, and developing significant electronic components and circuits domestically.

(i) The learners gained new knowledge about electrical protection and UPS, learned about the types of parts and materials.

(ii) There was a kind of resistance to the ineffectiveness of training and an emphasis on the effectiveness of other actions and initiatives among the beneficiaries of training programs.

(iii) The research team played the role of facilitator in the form of justifying how to obtain, summarize, and apply data in the designed model.

(iv) It was emphasized by the training officials that the designed approach should be institutionalized in the company and used from time to time.

(v) Items such as the salaries of the teaching staff were considered according to the time spent in different stages of training planning from needs assessment to evaluation.

(vi) Subindicators and standards were set to convert the activities performed into financial amounts.

(vii) Using the AHP approach and the defined pairwise comparison questionnaire, the weight of each of the mentioned factors in each of the observed or estimated effects was determined.

(viii) The experts in the field of training explained how to advance the activities, and the necessary training was provided to them. 
TABLE 1: Details of training costs.

\begin{tabular}{lc}
\hline Cost title & Description \\
\hline Instructors and lecturers & Tuition, transportation, catering, etc. \\
Training management and learning & Salary of educational staff in various processes of training, communication, etc. \\
Missed opportunity & Time spent training employees at different levels and not being active in the workplace \\
Educational space and facilities & Educational space, educational materials, teaching aids, etc. \\
Other costs & Reception of learners, transportation of learners, etc. \\
\hline
\end{tabular}

TABLE 2: Estimated amounts for training costs.

\begin{tabular}{lcc}
\hline Cost title & Electrical protection $(\$)$ & UPS (\$) \\
\hline Instructors and lecturers & 3823 & 2347 \\
Training management and learning & 434 & 230 \\
Missed opportunity & 4793 & 2758 \\
Educational space and facilities & 232 & 216 \\
Other costs & 81 & 73 \\
Total & 9364 & 5624 \\
\hline
\end{tabular}

TABLE 3: Achievements from training agreed upon by experts.

\begin{tabular}{lcccc}
\hline Module & Convertible achievements & CVR & Relevancy CVI & Clarity CVI \\
\hline \multirow{2}{*}{ Electrical protection } & Eliminate the bus bar trip & 0.83 & 0.92 & 0.83 \\
& Reduce time delay relay & 0.67 & 0.92 & 0.83 \\
\hline \multirow{3}{*}{ UPS } & Reduce device and equipment failure & 0.83 & 0.92 & 0.92 \\
& Reduce special consumable parts & 1.00 & 0.92 & 0.83 \\
\hline
\end{tabular}

TABLE 4: Elimination of bus bar trip as a result of electrical protection module implementation.

\begin{tabular}{|c|c|c|c|c|c|}
\hline \multicolumn{2}{|c|}{$\begin{array}{l}\text { Number of } \\
\text { breakdowns }\end{array}$} & \multirow[t]{2}{*}{ Rate of gas loss (million $\mathrm{m}^{3}$ ) } & \multirow[t]{2}{*}{ Condensate drop-out } & \multirow[t]{2}{*}{ Sulfur drop (tons) } & \multirow{2}{*}{$\begin{array}{c}\text { Total savings for } \\
\text { two years }(\$)\end{array}$} \\
\hline Before & After & & & & \\
\hline \multirow{3}{*}{$* * *$} & \multirow{3}{*}{0} & $\begin{array}{l}* * * \text { (Sale per cubic } \\
\text { meter } * * * \text { dollars) }\end{array}$ & $* * *$ (Sale per barrel $* * *$ dollars $)$ & $* * *$ (Sale per ton $* * *$ dollars) & 66261 \\
\hline & & $\begin{array}{l}* * * \text { (Sale per cubic } \\
\text { meter } * * * \text { dollars) }\end{array}$ & $* * *$ (Sale per barrel $* * *$ dollars $)$ & $* * *$ (Sale per ton $* * *$ dollars) & 13062 \\
\hline & & & Total & & 79323 \\
\hline
\end{tabular}

TABLE 5: Reduction of time delay relay as a result of electrical protection module implementation.

\begin{tabular}{lccccc}
\hline Number of relay types & Total number & Annual test title & \multicolumn{2}{c}{ Test time of each } \\
& & & \multicolumn{2}{c}{$\begin{array}{c}\text { type (person-hour) } \\
\text { Before }\end{array}$} & After \\
\hline 12 & 127 & Relay performance test & 10 & 5 & 766 \\
\hline
\end{tabular}

It should be noted that the holding of these training programs was not predetermined with a specific strategy and program and was voluntary and spontaneous and based on the attractions created during the series of training programs. Therefore, in the future, it is necessary to focus on educational needs assessment and appropriate goal setting. In addition, the goals should be pursued step by step with continuous monitoring and evaluation and to address shortcomings and improvements during implementation. 
TABLE 6: Reduction of device and equipment failure as a result of UPS module implementation.

\begin{tabular}{|c|c|c|c|c|}
\hline \multirow{3}{*}{ Device/module } & \multirow{3}{*}{ Code } & \multicolumn{2}{|c|}{ Number of failures in 10} & \multirow{3}{*}{ Estimated savings in 10 years $(\$)$} \\
\hline & & & & \\
\hline & & Before & After & \\
\hline$*-\mathrm{L} 2-\mathrm{E}-*-*$ & $* * *$ & 2 & 1 & 351 \\
\hline$*-\mathrm{L} 4-\mathrm{E}-*-*$ & $* * *$ & 2 & 1 & 294 \\
\hline$*-\mathrm{C} 3-\mathrm{E}-*-*$ & $* * *$ & 1 & 0.5 & 50 \\
\hline$*-\mathrm{C} 1-\mathrm{E}-*-*$ & $* * *$ & 1 & 0.5 & 73 \\
\hline$*-\mathrm{C} 2-\mathrm{E}-*-*$ & $* * *$ & 1 & 0.5 & 99 \\
\hline$*-\mathrm{L} 5-\mathrm{E}-*-*$ & $* * *$ & 2 & 1 & 2094 \\
\hline \multirow[t]{2}{*}{$*-\mathrm{UP} *$} & $* * *$ & 2 & 1 & 4852 \\
\hline & & & & 78129 \\
\hline
\end{tabular}

TABLE 7: Reduction of special consumable parts as a result of UPS module implementation.

\begin{tabular}{|c|c|c|c|c|c|}
\hline \multirow[t]{2}{*}{ Part name } & \multirow[t]{2}{*}{ Code } & \multicolumn{2}{|c|}{$\begin{array}{l}\text { Consumption } \\
\text { in ten years }\end{array}$} & \multirow[t]{2}{*}{ Unit price $(\$)$} & \multirow[t]{2}{*}{ Estimated savings in 10 years $(\$)$} \\
\hline & & Before & After & & \\
\hline IGBT & MODULE IGBT & 2 & 1 & 8938 & 894 \\
\hline Thyristor & SEMICRON-IXYS-SKKT-INFINEON & 16 & 4 & 1404 & 1685 \\
\hline PCB card & ALIP-CDIM-IGBT TRIG-THY TRIG-STABILIZER-MAIN BOARD-CCOT & 20 & 5 & 5618 & 8427 \\
\hline \multirow[t]{2}{*}{ Battery } & ALCAD-SAFT & 400 & 100 & 55414 & 1662411 \\
\hline & Total & & & & 1673417 \\
\hline
\end{tabular}

TABLE 8: Expected achievement of purchasing from domestic manufacturers as a result of UPS module implementation.

\begin{tabular}{|c|c|c|c|c|c|c|}
\hline \multirow[t]{2}{*}{ Part name } & \multirow[t]{2}{*}{ Code } & \multicolumn{2}{|c|}{$\begin{array}{c}\text { Number of purchases } \\
\text { in ten years }\end{array}$} & \multicolumn{2}{|c|}{ Unit price $(\$)$} & \multirow[t]{2}{*}{ Estimated savings in 10 years $(\$)$} \\
\hline & & Before & After & Domestic & Foreign & \\
\hline$* * *$ & $* * *$ & 0 & 5 & 766 & 1277 & 2555 \\
\hline$* * *$ & $* * *$ & 0 & 6 & 2043 & 4341 & 13788 \\
\hline$* * *$ & $* * *$ & 0 & 10 & 511 & 1277 & 7660 \\
\hline$* * *$ & $* * *$ & 0 & 5 & 511 & 2298 & 9040 \\
\hline \multirow[t]{2}{*}{$* * *$} & $* * *$ & \multirow{2}{*}{\multicolumn{2}{|c|}{ Total }} & 281 & 1532 & 12510 \\
\hline & & & & & & 45553 \\
\hline
\end{tabular}

TABLE 9: The weight of different factors in the indicators related to the observed effects.

\begin{tabular}{|c|c|c|c|c|c|}
\hline \multirow[b]{2}{*}{ Factor } & \multicolumn{2}{|c|}{ Electrical protection } & \multicolumn{3}{|c|}{ UPS } \\
\hline & $\begin{array}{l}\text { Eliminate the bus } \\
\text { bar trip }\end{array}$ & $\begin{array}{l}\text { Reduce time } \\
\text { delay relay }\end{array}$ & $\begin{array}{l}\text { Reduce device and } \\
\text { equipment failure }\end{array}$ & $\begin{array}{c}\text { Reduce special } \\
\text { consumable } \\
\text { parts }\end{array}$ & $\begin{array}{c}\text { Buy from } \\
\text { domestic suppliers }\end{array}$ \\
\hline $\begin{array}{l}\text { Attendance of people in the training } \\
\text { program }\end{array}$ & 16 & 9 & 15 & 5 & 5 \\
\hline $\begin{array}{l}\text { Learn from other sources and } \\
\text { methods (self-study, counseling, etc.) }\end{array}$ & 3 & 4 & 10 & 25 & 15 \\
\hline $\begin{array}{l}\text { Change in the process or method of } \\
\text { doing task }\end{array}$ & 14 & 16 & 15 & 15 & 15 \\
\hline $\begin{array}{l}\text { Improve the hardware and software } \\
\text { equipment }\end{array}$ & 4 & 2 & 5 & 10 & 10 \\
\hline $\begin{array}{l}\text { Improve workplace conditions } \\
\text { (physical facilities, light, and noise) }\end{array}$ & 3 & 21 & 5 & 5 & 5 \\
\hline Motivation of people to do the job well & 30 & 25 & 25 & 25 & 30 \\
\hline $\begin{array}{l}\text { How to employ people in the assigned } \\
\text { job or task }\end{array}$ & 30 & 23 & 25 & 15 & 20 \\
\hline
\end{tabular}


TABLE 10: Application of training-related weight to the electrical protection module financial achievement of the.

\begin{tabular}{lccc}
\hline Achievement & Coefficient of effect of participation in the program & $\begin{array}{c}\text { Financial achievement } \\
\text { in 5 years }\end{array}$ & $\begin{array}{c}\text { Financial achievement } \\
\text { from training }\end{array}$ \\
\hline Eliminate the bus bar trip & 16 & 198308 & 31729 \\
Reduce time delay relay & 9 & 32074 & 3830 \\
Total achievement of training & & 9364 & \\
Training cost & & 22710 & \\
Net profit & $243 \%$ & \\
ROI & & & \\
\hline
\end{tabular}

TABLe 11: Application of training-related weight to the UPS financial achievement.

\begin{tabular}{lccc}
\hline Achievement & Coefficient of effect of people's attendance & $\begin{array}{c}\text { Financial achievement } \\
\text { Financial achievement } \\
\text { from training }\end{array}$ \\
\hline Reduce device and equipment failure & 15 & 78129 & 11719 \\
Reduce special consumable parts & 5 & 1673417 & 83671 \\
Buy from domestic suppliers & 5 & 45553 & 2278 \\
Total achievement of training & & 97668 & 5 \\
Training cost & \multicolumn{3}{c}{5624} \\
Net profit & \multicolumn{3}{c}{92044} \\
ROI & \multicolumn{3}{c}{$1637 \%$} \\
\hline
\end{tabular}

TABLE 12: Irreversible effects on financial amounts due to educational modules.

\begin{tabular}{|c|c|c|}
\hline Module & Impact section & Achievement \\
\hline \multirow{3}{*}{$\begin{array}{l}\text { Electrical } \\
\text { protection }\end{array}$} & Training of expert human & No need for outside forces \\
\hline & resources & Less need for ongoing monitoring of the maintenance employees \\
\hline & $\begin{array}{c}\text { Adjusting the sting of protection } \\
\text { relays }\end{array}$ & Reducing the number of errors \\
\hline \multirow[b]{2}{*}{ UPS } & Manufacturing new parts & Manufacturing new parts within the company \\
\hline & Internal purchase & $\begin{array}{c}\text { Entrepreneurship in the production of new parts by domestic manufacturers and } \\
\text { purchase from them }\end{array}$ \\
\hline
\end{tabular}

\section{Conclusion}

In this study, using the general Phillips model and the AHP approach, the ROI for the training module related to UPS and electrical protection was calculated. These two fields are costly for the company, and the consequences of negligence or lack of sufficient competence in that regard are catastrophic. The financial impact of these important issues was not calculated and was not reflected in the rate of ROI. In calculating the ROI for the two training modules for electrical protection and UPS, which was carried out as a pilot project at the South Pars refinery, the researchers initially had the least relevant information. In fact, the calculation of ROI or basically any indicators related to cost and income or profit in the mentioned training programs has never been considered and, therefore, there was no necessary preparation to do so. However, with the follow-up of the researchers, the cooperation of the managers, and the efforts and perseverance of the experts, the necessary data were gradually collected, and step by step, the researchers reached a better common understanding. There was a kind of resistance to the ineffectiveness of training and an emphasis on the effectiveness of other actions and initiatives among the beneficiaries of training programs, which, of course, was recognized and not denied. However, top managers were surprised to see the achievement of training given its low cost. Therefore, the research team only played the role of facilitator in the form of justifying how to obtain, summarize, and apply data in the designed model and avoid any interference in the data and information. It was emphasized by the training officials that the designed approach should be institutionalized in the company and used from time to time. Therefore, the data extraction form related to design training costs and the necessary standards for extracting all costs were also determined. Finally, the report of the research activity was seen by the managers and experts of the company. The experts in the field of training also explained how to advance the activities, and the necessary training was provided to them to implement similar projects in the future.

\section{Data Availability}

Data are available and can be provided over the emails querying directly to the author (salimian.farhad@ut.ac.ir).

\section{Conflicts of Interest}

The author declares there are no conflicts of interest. 


\section{References}

[1] E. Ari, O. M. Karatepe, H. Rezapouraghdam, and T. Avci, "A conceptual model for green human resource management: indicators, differential pathways, and multiple pro-environmental outcomes," Sustainability, vol. 12, no. 17, Article ID 7089, 2020.

[2] G. K. Gosnell, J. A. List, and R. D. Metcalfe, "The impact of management practices on employee productivity: a field experiment with airline captains," Journal of Political Economy, vol. 128, no. 4, pp. 1195-1233, 2020.

[3] M. M. Karim, M. M. Choudhury, and W. B. Latif, "The impact of training and development on employees' performance: an analysis of quantitative data," Noble International Journal of Business and Management Research, vol. 3, no. 2, pp. 25-33, 2019.

[4] T. G. Deladem, Z. Xiao, S. Doku, T. T. Siueia, and K. Gyader, "The effectiveness of training and its impact on employee performance and productivity in the tourism sector of Ghana," European Journal of Economic and Financial Research, vol. 3, no. 5, 2019.

[5] D. A. DeCenzo, S. P. Robbins, and S. L. Verhulst, Fundamentals of Human Resource Management, John Wiley \& Sons, Hoboken, NJ, USA, 2016.

[6] C. C. Jasson and C. M. Govender, "Measuring return on investment and risk in training-A business training evaluation model for managers and leaders," Acta Commercii, vol. 17, no. 1, pp. 1-9, 2017.

[7] P. P. Phillips, The Bottomline on ROI: Basics, Benefits, \& Barriers to Measuring Training \& Performance Improvement, CEP Press, Moscow, Russia, 2002.

[8] A. Rotem, M. A. Zinovieff, and A. Goubarev, "A framework for evaluating the impact of the United Nations fellowship programmes," Human Resources for Health, vol. 8, no. 1, pp. $1-8,2010$.

[9] M. R. Sadeghi Moghadam, A. Mohaghar, and A. Sheikhkabir, "Simulation of pallet management system under risk pooling approach (case study of Saipa corporation supply chain)," Modern Research in Decision Making, vol. 1, no. 2, pp. 77-116, 2016.

[10] S. Li, B. Ragu-Nathan, T. Ragu-Nathan, and S. S. Rao, "The impact of supply chain management practices on competitive advantage and organizational performance," Omega, vol. 34, no. 2, pp. 107-124, 2006.

[11] O.-I. Dobre, "Employee motivation and organizational performance," Review of Applied Socio-Economic Research, vol. 5, no. 1, 2013.

[12] A. Alosta, O. Elmansuri, and I. Badi, "Resolving a location selection problem by means of an integrated AHP-RAFSI approach," Reports in Mechanical Engineering, vol. 2, no. 1, pp. 135-142, 2021.

[13] M. Bakır and Ö. Atalık, "Application of fuzzy AHP and fuzzy MARCOS approach for the evaluation of e-service quality in the airline industry," Decision Making: Applications in Management and Engineering, vol. 4, no. 1, pp. 127-152, 2021.

[14] Ç. Karamaşa, E. Demir, S. Memiş, and S. Korucuk, "Weighting the factors affecting logistics outsourcing," Decision Making Applications in Management and Engineering, vol. 4 , no. $1,2020$.

[15] A. Blagojević, S. Vesković, S. Kasalica, A. Gojić, and A. Allamani, "The application of the fuzzy AHP and DEA for measuring the efficiency of freight transport railway undertakings," Operational Research in Engineering Sciences: Theory and Applications, vol. 3, no. 2, pp. 1-23, 2020.
[16] E. Durmić, Ž. Stević, P. Chatterjee, M. Vasiljević, and M. Tomašević, "Sustainable supplier selection using combined FUCOM-Rough SAW model," Reports in mechanical engineering, vol. 1 , no. 1, pp. 34-43, 2020.

[17] O. F. Gorcun, S. Senthil, and H. Küçükönder, "Evaluation of tanker vehicle selection using a novel hybrid fuzzy MCDM technique," Decision Making: Applications in Management and Engineering, vol. 4, no. 2, pp. 140-162, 2021.

[18] M. Bakır, Ş. Akan, and E. Özdemir, "Regional aircraft selection with fuzzy piprecia and fuzzy marcos: a case study of the Turkish airline industry," Facta Universitatis - Series: Mechanical Engineering, vol. 19, no. 3, pp. 423-445, 2021.

[19] Ž. Jokić, D. Božanić, and D. Pamučar, "Selection of fire position of mortar units using LBWA and Fuzzy MABAC model," Operational Research in Engineering Sciences: Theory and Applications, vol. 4, no. 1, pp. 115-135, 2021.

[20] D. S. Pamučar and L. M. Savin, "Multiple-criteria model for optimal off-road vehicle selection for passenger transportation: BWM-COPRAS model," Vojnotehnički glasnik, vol. 68 , no. 1, pp. 28-64, 2020.

[21] Y. Ma and D. Bennett, "The relationship between higher education students' perceived employability, academic engagement and stress among students in China," Education+ Training, 2021.

[22] L. Zhang, X. Wang, Z. Zhang, Y. Cui, L. Ling, and G. Cai, “An adaptative control strategy for interfacing converter of hybrid microgrid based on improved virtual synchronous generator," IET Renewable Power Generation, 2021.

[23] N. Ghorbani and A. Korzeniowski, "Adaptive risk hedging for call options under cox-ingersoll-ross interest rates," Journal of Mathematical Finance, vol. 10, no. 4, pp. 697-704, 2020.

[24] X. Peng, Z. Liu, and D. Jiang, "A review of multiphase energy conversion in wind power generation," Renewable and Sustainable Energy Reviews, vol. 147, Article ID 111172, 2021.

[25] B. Li, G. Xiao, R. Lu, R. Deng, and H. Bao, "On feasibility and limitations of detecting false data injection attacks on power grid state estimation using D-FACTS devices," IEEE Transactions on Industrial Informatics, vol. 16, no. 2, pp. 854-864, 2019.

[26] X. Xu, D. Niu, B. Xiao, X. Guo, L. Zhang, and K. Wang, "Policy analysis for grid parity of wind power generation in China," Energy Policy, vol. 138, Article ID 111225, 2020.

[27] A. Korzeniowski and N. Ghorbani, "Put options with linear investment for Hull-White interest rates," Journal of Mathematical Finance, vol. 11, no. 1, pp. 152-162, 2021.

[28] N. Ghorbani and A. Korzeniowski, "Call and put option pricing with discrete linear investment strategy," 2021, https:// arxiv.org/abs/2110.04676.

[29] J. J. Phillips, "The return-on-investment (ROI) process: issues and trends," Educational Technology, vol. 38, no. 4, pp. 7-14, 1998.

[30] F. R. Rohs, "Return on Investment (ROI)," Journal of Leadership Education, vol. 3, no. 1, pp. 27-38, 2004.

[31] F. R. Rohs, "Return on investment (ROI): calculating the monetary return of a leadership development program," Journal of Leadership Education, vol. 3, no. 1, pp. 27-39, 2004.

[32] S. Sachdeva, "ROI of training and development programmes: challenges and developments," The SIJ Transactions on Industrial, Financial \& Business Management (IFBM), vol. 2, no. 6, pp. 284-289, 2014.

[33] X. Chen, T. Wang, R. Ying, and Z. Cao, "A fault diagnosis method considering meteorological factors for transmission networks based on P systems," Entropy, vol. 23, no. 8, p. 1008, 2021. 
[34] T. Wang, W. Liu, J. Zhao, X. Guo, and V. Terzija, "A rough set-based bio-inspired fault diagnosis method for electrical substations," International Journal of Electrical Power \& Energy Systems, vol. 119, Article ID 105961, 2020.

[35] W. Tao, X. Wei, J. Wang et al., "A weighted corrective fuzzy reasoning spiking neural $P$ system for fault diagnosis in power systems with variable topologies," Engineering Applications of Artificial Intelligence, vol. 92, Article ID 103680, 2020.

[36] H. Zhu, T. Wang, W. Liu, L. Valencia-Cabrera, M. J. PérezJiménez, and P. Li, "A fault analysis method for three-phase induction motors based on spiking neural P systems," Complexity, vol. 2021, Article ID 2087027, 19 pages, 2021.

[37] Q. Zhong, J. Yang, K. Shi, S. Zhong, Z. Li, and M. A. Sotelo, "Event-triggered $H_{\infty}$ load frequency control for multi-area nonlinear power systems based on non-fragile proportional integral control strategy," IEEE Transactions on Intelligent Transportation Systems, 2021.

[38] C. Teixeira and L. Pereira, "ROI in Training: how do HR Executives make investment decisions?" International Journal of Scientific and Research Publications, vol. 5, no. 7, pp. 1-6, 2015. 